\title{
Znaczenie rodziny królewskiej w praktyce ustrojowej i politycznej monarchii arabskich: Arabii Saudyjskiej, Jordanii i Maroka
}

\section{Monarchie arabskie - typologia}

Zajmując się badaniem rodzin królewskich, nie sposób rozpocząć analizy bez zdefiniowania pokrótce samego ustroju monarchicznego. Wychodząc od definicji zaproponowanej przez Andrzeja Antoszewskiego i Ryszarda Herbuta, monarchia rozumiana jest jako pewien sposób zarządzania państwem, którego ośrodek decyzyjny zlokalizowany jest w osobie dziedzicznego monarchy (króla, ale także cesarza, wielkiego księcia, cara). Antoszewski i Herbut przywołują historyczny podział monarchii na patrymonialne oraz absolutne. W pierwszych władca zarządzał państwem jako dobrem własnym, a samo państwo było rodzajem spadku, który był przekazywany kolejnym pokoleniom. W drugim monarcha jest jedynym i niepodzielnym władcą, niepodlegającym żadnym normom i regułom. Autorzy wskazują, że w obecnych czasach najczęściej występującym typem monarchii jest monarchia konstytucyjna (parlamentarna). Osoba monarchy często pełni w niej rolę symboliczną, władzę sprawuje za zgodą społeczeństwa i podlega obowiązującemu prawu¹.

W europejskiej przestrzeni politycznej zarówno monarcha jak i rodzina królewska zostały zmarginalizowane, obecnie pełniąc funkcje głównie reprezentacyjne. W literaturze przedmiotu skoncentrowanej na badaniach w obszarze Bliskiego Wschodu możemy odnaleźć różne definicje monarchii i jej podziału. Łukasz Fyderek dokonuje podziału monarchii na monarchie o reżimach organizacyjnych, do których zalicza się takie kraje jak Jordania, Maroko czy Oman oraz na monarchie o reżimach primordialnych: Arabia Saudyjska, Bahrajn, Katar, Kuwejt, ZEA. Podział

1 A. Antoszewski, R. Herbut (red.), Leksykon politologii, Wrocław 2004, s. 237-238. 
tych reżimów dotyczy kwestii, jaki typ instytucji politycznych dominuje w poszczególnych systemach politycznych ${ }^{2}$. Klasyfikacja naukowca jest rozwinięciem tzw. dychotomicznej typologii bliskowschodnich autorytaryzmów politycznych, wcześniej zaproponowanej przez Michaela Herba. Amerykański politolog dokonuje podziału na monarchie dynastyczne (Arabia Saudyjska, Kuwejt, Bahrajn, Katar i ZEA) oraz niedynastyczne (Maroko, Oman, Jordania). Monarchie dynastyczne cechują się swoistym włączeniem rodziny królewskiej do systemu politycznego. W początkowym okresie tworzenia się państwa rodzina królewska odgrywała istotną rolę w tworzeniu struktur administracyjnych i politycznych państwa. Monarchia niedynastyczna charakteryzuje się niewielkim znaczeniem rodziny królewskiej, z uwagi na nikłą liczebność jej samej, a w związku z tym trudność w obsadzeniu najważniejszych stanowisk w państwie ${ }^{3}$.

W tym rozumieniu Łukasz Fyderek zaznacza, że monarchie primordialne to takie systemy polityczne, których przywódcy kierowali się w swoim działaniu znaczeniem grupy tożsamościowej (rodziny, klanu, plemienia) przy obsadzaniu najważniejszych stanowisk państwowych. To oczywiście nie wyklucza istnienia nowoczesnych instytucji politycznych jak na przykład partii politycznych, ale na sposób ich ukształtowania zawsze ma wpływ wcześniej wspomniana grupa tożsamościowa. W tym typie zorganizowania systemu politycznego dana osoba w pierwszej kolejności jest elementem większej grupy społeczno-politycznej, a dopiero później pełni w nim funkcję polityczną. Przeciwieństwem są systemy polityczne organizacyjne, w których przynależność do danego rodu czy klanu nie odgrywa istotnej roli. W reżimach organizacyjnych dana osoba pełni po prostu swoją funkcję polityczną. Jej przynależność do danej grupy społecznej, nie odgrywa istotnej roli z punktu widzenia politycznego ${ }^{4}$.

Analogicznego podziału dokonuje Marcin M. Wiszowaty zwracając uwagę na podział monarchii na rodzinne oraz indywidualne. W świetle tej typologii przykładem monarchii rodzinnej jest Arabia Saudyjska. Marcin M. Wiszowaty do monarchii indywidualnych włącza natomiast Maroko,

2 Ł. Fyderek, Autorytarne systemy polityczne świata arabskiego. Adaptacja i inercja w przededniu Arabskiej Wiosny, Kraków 2018, s. 33.

3 Ibidem, s. 34.

4 Ibidem. 
Jordanię i Oman. Zasadniczy podział dotyczy znaczenia rodziny panującej dla systemu politycznego na korzyść monarchii rodzinnych ${ }^{5}$.

Zasadnym wydaje się zaznaczyć, że ustrój monarchiczny na Bliskim Wschodzie nie stanowi swego rodzaju przeżytku, co stanowi o randze rodziny panującej i pytania o jej miejsce w systemie politycznym. Jednym $\mathrm{z}$ istotnych elementów monarchii jest rodzina królewska, rozumiana jako pewna grupa osób, które łączą bezpośrednie relacje rodzinne z osobą monarchy. W tym przypadku monarcha staje się punktem odniesienia w poniższej analizie.

\section{Monarchia saudyjska - Saudowie}

W Królestwie Arabii Saudyjskiej rodzina królewska jest reprezentowana przez dynastię Saudów, której początki datuje się na 1744 r. Postać imama Muhammada ibn Sauda stała się w historii saudyjskiej monarchii symbolem narodzin dynastii, która w przyszłości miała dać początek saudyjskiej państwowości. Wartym wspomnienia jest fakt, że w aktach normatywnych państwa określenie „założyciel Arabii Saudyjskiej” odnosi się do osoby Abd al-Aziza ibn Abd al-Rahmana (określanego także jako Ibn Saud). Ibn Saud jest faktycznym założycielem państwa saudyjskiego i jego pierwszym monarchą, począwszy od 1932 r. Grzegorz Małachowski w swojej typologii określa Ibn Sauda jako twórcę trzeciego państwa saudyjskiego ${ }^{6}$. W zależności od źródeł, z których korzystają badacze, saudyjska rodzina królewska liczy dzisiaj od 5 tys. do 25 tys. jej członków ${ }^{7}$.

W ujęciu teorii polityki i czystych typów panowania Maxa Webera w Królestwie Arabii Saudyjskiej dominuje model sprawowania władzy w sposób tradycyjny. Źródłem władzy sprawowanej w sposób tradycyjny przez króla jest przede wszystkim religia (islam), która mocuje monar-

5 M.M. Wiszowaty, Zasada monarchiczna i jej przejawy we wspótczesnych ustrojach europejskich i pozaeuropejskich monarchii mieszanych, Gdańsk 2015, s. 463-464.

6 G. Małachowski, Następstwo tronu w Królestwie Arabii Saudyjskiej, [w:] Zmiany polityczne w państwach arabskich. Wybrane zagadnienia ustrojowe, red. A. Rothert, J. Szymanek, A. Zięba, Warszawa 2012, s. 256. Za twórcę pierwszego państwa saudyjskiego uznaje się Muhammada Ibn Sa’uda, który był faktycznym założycielem dynastii. Przywódcą drugiego państwa saudyjskiego był Turki Ibn Abd Allah.

7 Ibidem. 
chę ponad przepisami prawami państwowego. Król odpowiedzialny jest tylko przed Bogiem. Każdy następny monarcha jest Strażnikiem Dwóch Świętych Meczetów, symbolu kultu religijnego znajdującego się w Mekce i Medynie, co zapewnia saudyjskiej rodzinie królewskiej pewną nobilitację w świecie islamu, mimo że Saudowie nie wywodzą swojego rodowodu od Proroka Mahometa ${ }^{8}$. Można postawić tezę, że tradycyjny sposób sprawowania władzy nie wymaga atrybutów przepisów prawnych do zabezpieczenia systemu monarchicznego ${ }^{9}$.

Królestwo Arabii Saudyjskiej nie posiada skonsolidowanej konstytucji, dlatego podstawę analizy miejsca rodziny królewskiej w aktach normatywnych państwa stanowić będą dokumenty prawne ustanowione przez króla Fahda w 1992 r. Do najważniejszych dokumentów należą: Podstawowe prawo o sprawowaniu rządów (1992 r.), Prawo Prowincji (1992 r.), Prawo o Radzie Konsultacyjnej (1992 r.), Prawo o Radzie Ministrów (1993 r. $)^{10}$. Do analizy posłuży także prawo o Radzie Książąt, ustawione w 2006 r. przez króla Abdullaha.

Jednym z najważniejszych dokumentów saudyjskiego prawodawstwa jest „Podstawowe prawo o sprawowaniu rządów”. Dokument prawny, zawierający łącznie dziewięć rozdziałów, już na wstępie wspomina członków rodziny królewskiej. Z artykułu 5, który rozpoczyna rozdział 2, traktujący o prawodawstwie w Królestwie, dowiadujemy się, że władza w państwie będzie kolejno przekazywana prawowiernym synom założyciela Królestwa Arabii Saudyjskiej oraz ich potomkom.

Niniejsze prawo umożliwia objęcie tronu królewskiego każdemu męskiemu potomkowi Ibn Sauda, nie ogranicza tego przywileju tylko do jednego z synów władcy. Dziedziczność tronu odbywa się w linii poziomej (wszyscy synowie Ibn Sauda), ale także w pionowej (synowie synów Ibn Sauda). Tron nie jest dziedziczony tylko w linii pionowej, jak zwykło się przyjmować w monarchiach. Saudyjski sposób dziedziczenia królewskiego tronu umożliwia dostęp do niego większej ilości członków rodziny królewskiej ${ }^{11}$.

\footnotetext{
8 S. Marchand, Arabia Saudyjska. Zagrożenie, Warszawa 2004, s. 91.

9 K. Czajkowska, A. Diawoł-Sitko, Systemy polityczne wybranych państw Bliskiego Wscho$d u$, Warszawa 2012, s. 241.

10 G. Małachowski, System konstytucyjny Arabii Saudyjskiej, Warszawa 2011, s. 23.

11 The Embassy of the Kingdom of Saudi Arabia, Laws - Basic Law of Governance of Saudi Arabia, https://www.saudiembassy.net/basic-law-governance [dostęp: 15.05.2018].
} 
W artykule 5 personalnie wymieniona jest osoba Koronowanego Księcia, który w zachodniej perspektywie politycznej może być rozumiany jako wiceprezydent, zastępca najważniejszej osoby w państwie. W praktyce stanowisko Koronowanego Księcia obejmowała osoba bliska monarsze, nierzadko brat, czy w ostatnich latach syn panującego władcy. Niejednokrotnie funkcja Koronowanego Księcia jest wstępnym przygotowaniem do pełnienie roli monarchy w przyszłości ${ }^{12}$. Zgodnie z dokumentem, jakim jest „Podstawowe prawo o sprawowaniu rządów”, Korowany Książę posiada swoje indywidualne obowiązki i jest zaangażowany w bliską współpracę z monarchą. Jedną z najważniejszych prerogatyw Korowanego Księcia jest sprawowanie władzy w państwie od chwili śmierci monarchy ${ }^{13}$.

Koronowany Książę oprócz pełnienia funkcji drugiej osoby w państwie i współpracowania w głównej mierze z monarchą, jest jeszcze powiązany z ciałem kolegialnym - Radą Książąt. Rada Książąt funkcjonuje w oparciu o prawo o Radzie Książąt, ustanowione w 2006 r. przez poprzedniego monarchę, króla Abdullaha ${ }^{14}$. Dokument jest uzupełnieniem „Podstawowego prawa o sprawowaniu rządów”. Składa się z 25 artykułów. Już w pierwszym artykule dokumentu wyraźnie jest zaznaczone, że w skład tej instytucji wchodzą: wszyscy synowie założyciela Arabii Saudyjskiej, powołany przez aktualnego władcę syn zmarłego bądź ubezwłasnowolnionego (co musi potwierdzać stosowny raport medyczny) syna założyciela Arabii Saudyjskiej, pod warunkiem, że znany jest ze swej prawości i posiada stosowne kompetencje. Ponadto, do tego grona należy także jeden syn panującego króla oraz jeden syn panującego Koronowanego Księcia - obaj wybrani na podstawie swej prawości i kompetencji. W razie powstałego wakatu, król jest zobowiązany do wyznaczenia zastępstwa na to miejsce.

Po śmierci króla Rada Książąt jest zobowiązana do złożenia przysięgi wierności Koronowanemu Księciu, który od tego momentu jest osobą odpowiedzialną za sprawy państwowe ${ }^{15}$. Wybór osoby na stanowisko Koronowanego Księcia dokonuje się po wszystkich konsultacjach i uzy-

12 W historii Arabii Saudyjskiej większość Koronowanych Książąt obejmowało później tron królewski.

13 The Embassy..., op.cit.

14 Royal order (A/135), Law of pledge of allegiance commission, 19.10.2006, https://www. boe.gov.sa/ViewSystemDetails.aspx?lang=en \&SystemID=8\&VersionID=13 [dostęp: 4.04.2018] .

15 Ibidem. 
skaniu przysięgi wierności przez monarchę. Po tym czasie król ma możliwość wyznaczenia jednego, dwóch lub trzech kandydatów, którzy byliby najlepszymi kandydatami na to stanowisko. W dokumencie nie określono wieku, kompetencji, czy wykształcenia przyszłego Koronowanego Księcia. Zadaniem Rady Książąt jest udzielenie kolegialnego poparcia, dla któregoś z wyznaczonych przez monarchę kandydatów. W innym wypadku Rada Książąt wyznacza swojego kandydata i przedstawia go monarsze. Jeśli i w tym przypadku wybór nie uzyska akceptacji, nominacji dokonuje się poprzez głosowanie w Radzie. Koronowany Książę powinien zostać wybrany w terminie nieprzekraczającym 30 dni od ślubowania wierności przez króla ${ }^{16}$.

Jednym z najistotniejszych zapisów dokumentu jest artykuł 12, który precyzuje obowiązki Rady Książąt w przypadku czasowej lub permanentnej niedyspozycji dwóch najważniejszych osób w państwie - zarówno monarchy, jak i Koronowanego Księcia. Obowiązki administracyjne przejmuje wówczas Tymczasowa Rada Zarządzająca, zaś Rada Książąt ma za zadanie wyznaczyć najodpowiedniejszą osobę na stanowisko monarchy w ciągu siedmiu dni. Taka sama procedura dotyczy ewentualnej śmierci monarchy i Koronowanego Księcia.

Kolejną osobą wyróżnioną stanowiskiem na tle rodziny królewskiej jest przewodniczący Rady Książąt, który jest najstarszym synem założyciela królestwa, natomiast reprezentant Rady Książąt jest drugim co do starszeństwa synem. Jeśli obaj są nieobecni posiedzenia Rady powinny być prowadzone przez najstarszego syna z synów, wchodzących w skład Rady.

Posiedzenia Rady Książąt odbywają się w formie tajnej, co jeszcze bardziej podkreśla elitarność tej grupy ${ }^{17}$.

Dominującą linią wewnątrz saudyjskiej rodziny królewskiej jest oczywiście linia Saudów, ale królewska rodzina posiada jeszcze kilka gałęzi, tj. ród al-Farhanów, As-Sunajjan, Al-Miszari, At-Turki oraz Al-Dżuluwi ${ }^{18}$. Obecnie dominującą grupą osób wewnątrz saudyjskiej rodziny królewskiej jest ród As-Sudajri, który swoje nazewnictwo czerpie od nazwiska żony Abd al-Aziza ar-Rahmana - Hussy bint Ahmad as-Sudajri. Władca

\footnotetext{
16 Ibidem.

17 Royal order (A/135)..., op.cit.

18 G. Małachowski, System..., op.cit., s. 45.
} 
darzył kobietę szczególną sympatią i doczekał się z nią siedmiu synów: Fahda, Sultana, Abd ar-Rahmana, Najifa, Turkiego, Salmana, Ahmada, określanych czasem przydomkiem „siedmiu braci”"

Mimo że w Arabii Saudyjskiej nie ma partii politycznych, istnieje polityczna rywalizacja, którą można zaobserwować na przykładzie obsadzania stanowisk politycznych, takich jak chociażby Koronowany Książę. Funkcję Koronowanego Księcia pełniło do tej pory 12 członków saudyjskiej rodziny królewskiej. Byli to: Saud, Fajsal, Muhammad, Chalid, Fahd, Abd Allah Sultan, Najif, Salman, Mukrin, Muhammad bin Najif, Muhammad bin Salman $^{20}$. Pierwszych 10 Koronowanych Książąt było synami założyciela państwa, Abd al-Aziza ar-Rahmana, z czego czterech z nich to jednocześnie synowie Hussy bint Ahma as-Sudajri. W ostatnim czasie funkcja Koronowanego Księcia przypadła kolejnemu pokoleniu, wnukom Ibn Sauda oraz Hussy. Są oni jednocześnie synami wcześniej panujących królów -Najifa i Salmana. Obecnie stanowisko Koronowanego Księcia zajmuje 32-letni Muhammad bin Salman. Wybór nowego księcia, Muhammada bin Salmana, pokazuje wzmacnianie w ostatnich latach tej właśnie gałęzi rodziny królewskiej - klanu Sudajrich ${ }^{21}$.

Wartym odnotowania jest fakt, że drogę do saudyjskiego tronu dla szerszego grona osób otworzył inicjator reform politycznych i twórca „ustawy zasadniczej” Arabii Saudyjskiej, król Fahd. Do czasu panowania władcy, tron był dziedziczony tylko przez synów założyciela państwa, Abd al-Aziza ar-Rahmana. Adnotacja królewska zaznaczała, że każdy syn założyciela państwa powinien zasiąść na królewskim tronie. To oznaczało, poza regułą starszeństwa, dziedziczność tronu tylko w linii poziomej. Król Fahd dokonał zmiany w zapisach ustawy zasadniczej dopuszczając do tronu także wnuków założyciela państwa, co jednocześnie powodowało, że od tej pory pretendentami do tronu było nawet kilkaset osób. Początkowo następców tronu było około 30 (założyciel państwa posiadał ok. 17 żon). Zmiana zapisów w akcie prawnym miała być pragmatycznym działaniem, które stanowiło odpowiedź na pytanie, czy i jaka będzie rola kolejnego

19 S. Marchand, Arabia..., op.cit., s. 124.

20 G. Małachowski, System..., op.cit., s. 45.

21 Saudi Crown Prince Mohammed bin Salman, Power behind the throne, BBC News, 7.03.2018, http://www.bbc.com/news/world-middle-east-40354415 [dostęp: 4.04.2018]. 
pokolenia Saudów. Ówczesny władca był przekonany, że ten zapis spowoduje zmianę i powoli będzie kończył erę „sędziwych braci” ${ }^{22}$. Należy mieć na względzie także fakt, że dla króla Fahda taka zmiana polityczna oznaczała, że pierwszymi spadkobiercami, których obejmie nowe prawo będą jego synowie. Tak się nie stało, synowie króla Fahda byli skompromitowani poprzez skandale oraz zbyt młodzi, by zasiąść na saudyjskim tronie. Ostatecznie władzę po królu Fahdzie objął jego przyrodni brat Abd Allah w 2005 roku²

Członkowie rodziny królewskiej Saudów zajmują obecnie kilka prominentnych stanowisk w państwie: ministra straży narodowej (Mutaib bin Abd Allah bin Abd al-Aziz Al Saud), ministra spraw wewnętrznych (Abd al-Aziz bin Saud bin Najif Abd al-Aziz Al Saud). Pozostałe stanowiska polityczne nie są obejmowane przez członków rodziny panującej Saudów, co koresponduje z polityką otwarcia nowego monarchy i jego syna. Jednocześnie król mianuje na te stanowiska osoby z wysokimi tytułami naukowymi, przeciwstawiając się skostnieniu ideowemu starszych członków rodziny królewskiej ${ }^{24}$. W poprzednich latach wysokie stanowiska ministerialne w państwie piastowali członkowie saudyjskiej rodziny królewskiej: w przypadku Fajsala były to stanowiska premiera, wicepremiera oraz ministra spraw zagranicznych, w sytuacji Chalida było to stanowisko wicepremiera, w przypadku Fahda były to stanowiska wicepremiera oraz ministra do spraw edukacji. Poprzedni król Abd Allah sprawował funkcję wojskową, przewodząc Gwardii Narodowej ${ }^{25}$.

Najistotniejszą rolę w saudyjskiej rodzinie królewskiej odgrywają mężczyźni, z ogromną przewagą mężczyzn w podeszłym wieku. Saudowie zabezpieczyli interesy polityczne swojej rodziny poprzez ustanowienie aktów normatywnych i utworzenie organu kolegialnego, którego ściśle wyselekcjonowane grono zajmuje się wyborem Koronowanego Księcia i monarchy. Według Grzegorza Małachowskiego pozycja polityczna danego członka rodziny królewskiej zależy od pozycji oraz kontaktów jego ojca.

\footnotetext{
22 S. Marchand, Arabia..., op.cit., s. 111.

23 Ibidem, s. 134-137.

24 House of Saud, Saudi Royal Family, News E Information, http://houseofsaud.com/ [dostęp: 4.04.2018].

25 G. Małachowski, System..., op.cit., s. 45.
} 
Sam autorytet rodzica wystarcza nieraz, by zapewnić osobie polityczny awans $^{26}$.

Arabia Saudyjska nie jest wolna od protestów swoich obywateli. Społeczeństwo, które jest coraz bardziej wykształcone i ma dostęp do informacji pochodzących z mediów społecznościowych, domaga się zmiany obowiązujących reform ${ }^{27}$. Postępująca liberalizacja, jak chociażby przyznanie prawa jazdy kobietom, nasuwa pytanie czy Królestwo Arabii Saudyjskiej zdecyduje się w przyszłości na szerszą obecność płci żeńskiej w przestrzeni społeczno-politycznej oraz dopuszczenie kobiet do męskiego gremium rodziny królewskiej.

\section{Monarchia jordańska - Haszymidzi}

Jordańska rodzina królewska wywodzi się z rodu Haszymidów, którzy źródło swojego pochodzenia czerpią od samego Proroka Muhammada. Uznaje się, że obecny król Jordanii Abd Allah II jest potomkiem w 43 pokoleniu założyciela islamu ${ }^{28}$. W Królestwie Jordanii obowiązuje ustawa zasadnicza, która została przyjęta w 1952 r. Podczas jej obowiązywania swoje rządy sprawowało dwóch królów, a wraz z nimi ich rodziny: Husajn ibn Talal, a następnie jego syn Abd Allah II. Obecny król sprawuje swoją władzę od 1999 r.

Ustawa zasadnicza Królestwa Jordanii składa się z dziewięciu rozdziałów. Jednym z najistotniejszych artykułów dotyczących rodziny królewskiej jest artykuł 28, w rozdziale 4, dotyczącym króla i jego prerogatyw. Artykuł posiada 13 podpunktów, które opisują proces sukcesji do jordańskiego tronu ${ }^{29}$.

Jordański tron jest dziedziczny w sposób patriarchalny, w linii bezpośredniej od najstarszego syna Abd Allaha ibn al-Husajna. W chwili śmierci syna, tron jest przekazywany w linii pionowej. Dziedziczenie w linii poziomowej, czyli z włączeniem do jordańskiej korony któregoś z braci, jest możliwe tylko w sytuacji, kiedy panujący monarcha umrze nie zostawiając

\footnotetext{
26 Ibidem, s. 42-45.

27 K. Czajkowska, A. Diawoł-Sitko, Systemy polityczne..., op.cit., s. 252-255.

28 J. Zdanowski, Arabia Saudyjska, Warszawa 2004, s. 306-309.

29 The Constitution of The Hashemite Kingdom of Jordan, www.refworld.org/pdfid/3ae6b53310.pdf [dostęp: 4.04.2018].
} 
męskiego potomka. Gdyby tak się zdarzyło, tron dziedziczy jego najstarszy brat, a potem najstarszy syn. Gdyby i ten pozostawał bez męskiego potomka, tron jest dziedziczony przez synów pozostałych braci, zgodnie z zasadą starszeństwa. Gdyby linia rodzinna była pozbawiona męskich potomków i siostrzeńców, korona jordańska przechodzi, zgodnie z powyższą zasadą, do wujów i ich potomków. Jeśli mimo powyższych założeń nie uda się wyznaczyć osoby do jordańskiego tronu, za jej wyznaczenie odpowiada ciało parlamentarne - Zgromadzenie Narodowe. Jest ono zobowiązane do wyznaczenia kandydata, który byłby spadkobiercą założyciela Jordanii ${ }^{30}$.

Konstytucja Królestwa Jordanii przewiduje także zapis co do osoby małżonki monarchy. Z ustawy zasadniczej dowiadujemy się, że rodzicami następcy tronu muszą być prawowierni muzułmanie, a zatem i małżonka króla powinna być muzułmanką. Męscy członkowie rodziny królewskiej mogą zostać wykluczeni z możliwości otrzymania tronu królewskiego na mocy dekretu królewskiego z przyczyn, jak to precyzuje konstytucja, „nieprzydatności”. „Nieprzydatność” orzeka monarcha we współudziale z Prezesem Rady Ministrów oraz czterema ministrami, w tym ministrem spraw wewnętrznych oraz ministrem sprawiedliwości.

Członek rodziny królewskiej, który zostaje następcą tronu, a nie ma ukończonego 18 roku życia, w chwili śmierci monarchy zostaje królem tylko nominalnie. Jego pozycja jest zależna od Regenta/Rady Regencji, którzy wykonują uprawnienia królewskie na mocy dekretu królewskiego nadane jeszcze za życia poprzedniego monarchy. Jeśli król nie dokona takiego zapisu przed swoją śmiercią, formalnościami zajmuje się Rada Ministrów ${ }^{31}$.

Męscy przedstawiciele rodziny królewskiej mają możliwość objęcia takich funkcji jak: regent, wiceregent, członek Rady Regencji lub członek Rady Wiceregencji po ukończeniu 18 roku życia. Osoba niezwiązana więzami krwi z rodziną królewską również ma możliwość objęcia wspomnianych stanowisk, pod warunkiem ukończenia 30 roku życia w momencie kandydowania na to stanowisko ${ }^{32}$.

Jordańska ustawa zasadnicza nie wspomina więcej razy w swoich zapisach któregoś z członków rodziny królewskiej. Wydaje się, że najważniej-

\footnotetext{
30 Ibidem.

31 Ibidem.

32 Ibidem.
} 
szą osobą spośród rodziny królewskiej, której poświęca się miejsce poprzez szczegółowe rozpisanie prawa sukcesyjnego, jest osoba następcy tronu. Nie bez znaczenia jest także postać małżonki monarchy, która niezależnie od swojego pochodzenia, jest zobowiązana do konwersji na islam ${ }^{33}$.

Królestwo Jordanii nie może poszczycić się tak liczną rodziną królewską jak Królestwo Arabii Saudyjskiej, co czyni jej członków nieanonimowymi członkami życia społeczno-politycznego. Ścisła jordańska rodzina królewska liczy sześć osób: króla Abd Allaha II, jego żonę królową Ranię oraz ich czwórkę dzieci: Husajna, Imana, Salmę oraz Haszima. Trójka z nich już osiągnęła pełnoletniość. Najmłodszy członek rodziny królewskiej, książę Haszim, ma obecnie 13 lat. Najstarszy syn pary królewskiej, Husajn, jest pierwszym następcą tronu ${ }^{34}$.

Znaczącą postacią w życiu społeczno-politycznym Królestwa Jordanii jest małżonka króla Abd Allaha II. Jordańska ustawa zasadnicza nie precyzuje listy kompetencji pierwszej damy. Mimo to królowa Rania z ogromnym zaangażowaniem włącza się w działalność publiczną męża. Królowa Rania jako matka czwórki dzieci, muzułmanka i jednocześnie żona króla, nie pełni tradycyjnej roli kobiety dla tego regionu świata. Nie pozostaje w ukryciu i nie ogranicza swojej działalność do życia rodzinnego. Królowa swoją publiczną działalność kieruje przede wszystkim na dwa obszary - edukację i przedsiębiorczość. Szczególnie bliskie jej są problemy dzieci oraz kobiet, także kobiet jako matek. W swoich działaniach skupia się na polepszeniu infrastruktury edukacyjnej, a także poszukuje sposobów zaangażowania się kobiet z najniższych warstw społecznych w pracę zawodową ${ }^{35}$.

Nie ogranicza się tylko do słów, ale z powodzeniem powołuje instytucje, które mają realizować jej wizję w rzeczywistości. Do takich instytucji należy Fundacja Rzeki Jordan, organizacja pozarządowa powstała w 1995 r. Instytucja skupia się przede wszystkich na rozwiązywaniu takich problemów jak ochrona dzieci, czy zapobieganie przemocy wobec najmłodszych ${ }^{36}$. Statystyki organizacji pokazują, jak znaczący wpływ ma

\footnotetext{
33 Ibidem.

34 Ibidem.

35 I. Król, Sposoby kreowania wizerunku monarchy w Jordanii, Maroku i Arabii Saudyjskiej, [w:] Kultura popularna na Bliskim Wschodzie, red. K. Górak-Sosnowska, K. Pachniak, Warszawa 2012, s. 213.

36 Jordan River Foundation, Who we are, https://www.jordanriver.jo/en [dostęp: 4.04.2018].
} 
działalność fundacji na społeczeństwo jordańskie. Tylko na przestrzeni dwóch lat ponad 82 tys. rodzin, kobiet i dzieci otrzymało pomoc, a ponad 35 członków organizacji odbyło profesjonalne przeszkolenie ${ }^{37}$.

Królowa Rania jest głosem nie tylko w swoim kraju, ale także poza granicami Jordanii, poruszając tematykę edukacji i przedsiębiorczości na forum światowym. Jest reprezentantką krajów arabskich na Światowym Forum Ekonomicznym. Na forum publicznym podnosiła takie tematy jak prawa kobiet czy bezrobocie $\mathrm{w}$ regionie ${ }^{38}$. Żona króla nie obawia się także korzystania z najnowszych technologii, czego wyrazem było założenie własnego kanału na YouTube. Na platformie starała się przełamać stereotypy dotyczące muzułmanów i Arabów oraz przedstawić ich prawdziwy wizerunek $^{39}$. Królowa Rania, chociaż nie przewidziano dla niej znaczącego miejsca w ustawie zasadniczej Jordanii, stara się prowadzić swoją działalność jako swojego rodzaju dopełnienie polityki króla. Swoją pozycję buduje w oparciu o charyzmę, a nie przepisy prawne.

Ukształtowanie systemu politycznego Królestwa Jordanii sprawia, że większość krytyki wobec podejmowanych decyzji politycznych spoczywa na osobie pełniącej funkcję premiera. W Jordanii pojawiają się protesty zorganizowanych grup społecznych, ale na tle całego regionu są one niewielkie. Co więcej, Jordańczycy w porównaniu z innymi krajami Bliskiego Wschodu, zachowują dość dużą swobodę, jak np. prawo do krytyki władzy. W związku z tym opinia na temat rodziny królewskiej jest względnie pozytywna ${ }^{40}$.

\section{Monarchia marokańska - Alawici}

Władzę w Królestwie Maroka sprawuje dynastia Alawitów. Na jej czele stoi obecnie panujący król Muhammad VI. Razem ze swoją żoną Lallą

37 Ibidem. Statystyki dotyczą lat 2015-2017.

38 Media Center, Women's Leadership Initiative - WEF, https://www.queenrania.jo/en/ media/articles/womens-leadership-initiative-wef [dostęp: 4.04.2018].

39 Queen Rania, Jordan's Queen Rania on Arab women, https://www.youtube.com/ watch?v=jyCB-ULChV4 [dostęp: 4.04.2018].

40 B. Wróblewski, Haszymidzkie Królestwo Jordanii - między autorytarna tradycją a demokratyzacją, [w:] Bliski Wschód coraz bliżej red. J. Danecki, S. Sulkowski, Warszawa 2011, s. 279-280. 
Salmą Bennani tworzą królewską parę, która posiada dwójkę potomstwa - Mulaja Hassana oraz Chadidżę. Żadne z dzieci nie osiągnęło jeszcze pełnoletniości. Ponadto król Muhammad VI posiada trzy siostry oraz jednego brata. Jego rodzeństwo to: Lalla Mariam, Lalla Asma, Lalla Hasna oraz Mulaj Raszid ${ }^{41}$.

Królestwo Maroka funkcjonuje w oparciu o ustawę zasadniczą przyjętą w 2011 r., po uprzednio zorganizowanym referendum konstytucyjnym. Zmiany ustawy zasadniczej dokonał obecnie panujący król Muhammad $\mathrm{VI}^{42}$. Ustawa zasadnicza posiada 14 rozdziałów ${ }^{43}$. Rodzinie królewskiej, a w zasadzie jej męskim reprezentantom, poświęcone są dwa artykuły ustawy zasadniczej (art. 43-44). Zgodnie z zapisem aktu normatywnego, korona królewska jest dziedziczna. Jej spadkobiercami są wszyscy synowie króla Muhammada VI, zgodnie z zasadą primogenitury, czyli starszeństwa. Oczywiście król ma prawo powołać na następcę tronu innego syna, pomijając najstarszego i będzie to wciąż zgodne z literą marokańskiego prawa. Jeśli natomiast panujący król nie posiada męskich potomków, marokańska korona jest dziedziczona przez mężczyzn w linii bocznej, zgodnie z powyższą zasadą.

Niepełnoletni następca tronu z chwilą śmierci Muhammada VI zostaje królem w znaczeniu nominalnym. Od tego momentu współpracuje z Radą Regencyjną jako ciałem doradczym, do momentu ukończenia 20 roku życia. Rada Regencyjna posiada królewskie prerogatywy. Nie ma natomiast możliwości zmiany ustawy zasadniczej. Niepełnoletni król współpracuje z osobami, które pełnią następujące funkcje: Prezes Sądu Konstytucyjnego, Przewodniczący Izby Reprezentantów, Szef Rządu, Przewodniczący Izby Radców, Prezes Wysokiej Rady Władzy Sądowniczej, sekretarz generalny wysokiej Rady Naukowej oraz dziesięć osób, które mianuje uprzednio król. Wszystkie te osoby są członkami Rady Regencyjnej ${ }^{44}$.

Artykuły marokańskiej ustawy zasadniczej dotyczące rodziny królewskiej, analogicznie jak jordańskiej, najwięcej miejsca poświęcają zapisom,

41 Europa Biographical Reference, World Who's Who, Morocco, http://www.worldwhoswho.com/public/views/royal_families.html?country=MOROCCO [dostęp: 4.04.2018].

42 M. Ottaway, The Moroccan Constitution: Real change or more of the same?, Carnegie Endowment for International Peace, https://carnegieendowment.org/2011/06/20/new-moroccan-constitution-real-change-or-more-of-same-pub-44731 [dostęp: 4.04.2018].

43 Biblioteka Sejmowa, Konstytucje świata, Królestwo Maroka..., op.cit.

44. Ibidem. 
które zapewniają ciągłość korony. Ustawa zasadnicza Maroka w odróżnieniu od ustawy zasadniczej Jordanii nie precyzuje, czy król powinien być muzułmaninem i synem rodziców wyznających islam. $Z$ tego względu być może przepisy nie precyzują wyznania pierwszej damy, chociaż konstytucja podkreśla, że Królestwo Maroka jest krajem wyznaniowym, z dominująca religią, jaką jest islam ${ }^{45}$.

Jak zostało wspomniane, ścisła rodzina królewska Maroka nie jest liczna, a potomkowie pary królewskiej nie osiągnęli jeszcze pełnoletniości. Z tego względu swoją uwagę przyciąga król z racji pełnionego urzędu, ale także małżonka monarchy. Lalla Salma Bennani to pochodząca z Maroka absolwentka kierunków ścisłych, w tym informatyki. Jest tytułowana księżną, choć do tej pory nie było takiego zwyczaju. Nie nosi tytułu królowej. Księżna Lalla Salma, pomimo braku zapisów prawnych dotyczących jej pozycji w państwie nie ogranicza się tylko do pełnienia funkcji żony króla. Lalla Salma, podobnie jak jordańska królowa Rania, nie nosi tradycyjnego nakrycia głowy, a jedynie suknie charakterystyczne dla Maroka. Tym sposobem przydaje rodzinie królewskiej nowoczesności ${ }^{46}$.

Księżna Salma angażuje się w działania prospołeczne, a jednym z jej głównych zainteresowań jest walka z rakiem u dorosłych i dzieci. Dzięki założonemu stowarzyszeniu Lalla Salma stara się o dostęp do opieki medycznej dla swoich poddanych, a także by taka opieka jak najszybciej dotarła do potrzebującego. Za swoje działania pro publico bono księżna otrzymała tytuł ambasadora dobrej woli, przyznawany przez Światową Organizację Zdrowia ${ }^{47}$. Małżonka Muhammada VI bierze także udział w licznych spotkaniach na szczeblu międzynarodowym, nierzadko bez męża, reprezentując go na arenie międzynarodowej ${ }^{48}$.

W 2011 roku fala demonstracji doprowadziła do zmian konstytucyjnych w Królestwie Maroka. Król wraz ze swoim otoczeniem politycznym przygotował ustawę zasadniczą, która jest jedną z najbardziej liberalnych w regionie. Była to odpowiedź na protesty grup młodych i wykształconych Marokańczyków. Szybka reakcja Muhammada VI spotkała się z aprobatą

\footnotetext{
Ibidem.

Ibidem.

47 I. Król, Sposoby kreowania..., op.cit., s. 216.

48 Ibidem.
} 
społeczeństwa, które odebrało władcę jako rozumiejącego potrzeby swoich obywateli ${ }^{49}$.

\section{Wnioski}

Analizowane arabskie monarchie - Arabia Saudyjska, Jordania, Maroko w swoich ustawach zasadniczych w odmiennym stopniu poświęcają uwagę rodzinie królewskiej. Konstytucje Haszymidzkiego Królestwa Jordanii oraz królestwa Maroka niewiele miejsca poświęcają rodzinie królewskiej. Artykuły dotyczące poszczególnych członków rodziny królewskiej są zawężone do opisu prawa sukcesyjnego. Prawo to samo w sobie gwarantuje pozycję obecnie żyjącym członkom rodziny królewskiej, ale także ich potomkom.

Istotną kwestią jest też system polityczny, w którym umiejscowiona jest rodzina królewska. Jordania i Maroko to monarchie konstytucyjne, posiadające parlamenty. $\mathrm{Z}$ tego względu mniej miejsca poświęca się rodzinie królewskiej w aktach normatywnych. Rodziny królewskie tych państw skupiają się na działalności nakierowanej na ich społeczeństwa. Nie bez powodu żonami królów Jordanii i Maroka są kobiety wykształcone i udzielające się na arenie międzynarodowej. Ich wizerunek i autorytet w kraju oraz za granicą wynika z ich własnych cech osobowych, a nie z konstytucji.

Inaczej sytuacja przedstawia się w Królestwie Arabii Saudyjskiej. Istnieje wiele przepisów prawnych poświęconych rodzinie królewskiej; ciągle powstają nowe dokumenty dotyczące bezpośrednio wybranych członków rodziny królewskiej, jak chociażby Rada Książąt. W Arabii Saudyjskiej istotną postacią jest osoba Koronowanego Księcia. Dużą rolę odgrywa też Rada Książąt. Razem z monarchą tworzą triadę współpracujących ze sobą organów. Niewątpliwie rozległe prawodawstwo w tym zakresie ma na celu ograniczyć wpływy osób o poglądach niewygodnych z punktu widzenia panującego monarchy. Duża liczebność rodziny królewskiej oraz waśnie wewnątrz rodu spowodowały, że poprzedni król Abdullah zdecydował się na wprowadzenie osobnego prawa dotyczącego Rady Książąt. To posunięcie w jeszcze większym stopniu spowodowało zamknięcie tej grupy oraz

49 E. Popławska, Recepcja zasad zachodniego konstytucjonalizmu (na przykładzie Maroka), [w:] Zmiany polityczne w państwach arabskich. Wybrane zagadnienia ustrojowe, red. A. Rothert, J. Szymanek, A. Zięba, Warszawa 2012, s. 35. 
skupienie władzy w rękach bardzo niewielkiej grupy osób, wyselekcjonowanej z rodziny Saudów.

Wydaje się, że pomimo różnic dzielących arabskie rodziny królewskie stanowią one spoiwo podtrzymujące systemy polityczne swoich krajów. Być może inny od dotychczasowego rodzaj praw dla rodziny królewskiej byłby nie do zaakceptowania przez pozostałe organy polityczne oraz społeczeństwo, a obecny ich kształt, zapewnia względną stabilizację opisanych systemów politycznych.

\section{Bibliografia}

Antoszewski A., Herbut R. (red.), Leksykon politologii, Wrocław 2004.

Czajkowska K., Diawoł-Sitko A., Systemy polityczne wybranych państw Bliskiego Wschodu, Warszawa 2012.

Fyderek Ł., Autorytarne systemy polityczne świata arabskiego. Adaptacja i inercja w przededniu Arabskiej Wiosny, Kraków 2018.

Danecki J., Sulkowski S., Bliski Wschód coraz bliżej, Warszawa 2011.

Król I., Sposoby kreowania wizerunku monarchy w Jordanii, Maroku i Arabii Saudyjskiej, [w:] Kultura popularna na Bliskim Wschodzie, red. K. Górak-Sosnowska, K. Pachniak, Warszawa 2012.

Małachowski G., System konstytucyjny Arabii Saudyjskiej, Warszawa 2011. Rothert A., Szymanek J., Zięba A., Zmiany polityczne w państwach arabskich. Wybrane zagadnienia ustrojowe, Warszawa 2012.

Wiszowaty M.M., Zasada monarchiczna i jej przejawy we wspótczesnych ustrojach europejskich i pozaeuropejskich monarchii mieszanych, Gdańsk 2015, wyd. Uniwersytetu Gdańskiego.

Zdanowski J., Arabia Saudyjska, Warszawa 2004.

\section{Źródła internetowe}

Europa Biographical Reference, World Who's Who, Morocco, http://www. worldwhoswho.com/public/views/royal_families.html?country=MOROCCO.

House of Saud, Saudi Royal Family, News E Information, http://houseofsaud.com/. 
Jordan River Foundation, Who we are, https://www.jordanriver.jo/en.

Ottaway M., The Moroccan Constitution: Real change or more of the same?,

Carnegie Endowment for International Peace, https://carnegieendowment.org/2011/06/20/new-moroccan-constitution-real-change-or-more-of-same-pub-44731.

Queen Rania, Jordan's Queen Rania on Arab women, https://www.youtube.com/watch?v=jyCB-ULChV4.

Royal order (A/135), Law of pledge of allegiance commission, 19.10.2006, https://www.boe.gov.sa/ViewSystemDetails.aspx?lang=en\&Syste$\mathrm{mID}=8 \&$ VersionID $=13$.

Saudi Crown Prince Mohammed bin Salman, Power behind the throne, BBC News, 7.03.2018, http://www.bbc.com/news/world-middle-east-40354415.

The Constitution of The Hashemite Kingdom of Jordan, www.refworld.org/ pdfid/3ae6b53310.pdf.

The Embassy of the Kingdom of Saudi Arabia, Laws - Basic Law of Governance of Saudi Arabia, https://www.saudiembassy.net/basic-lawgovernance.

Saudi Crown Prince Mohammed bin Salman, Power behind the throne, http://www.bbc.com/news/world-middle-east-40354415.

Women's Leadership Initiative - WEF, https://www.queenrania.jo/en/me$\mathrm{dia} /$ articles/womens-leadership-initiative-wef.

\section{Constitutional and political role of the royal family in Arab monarchies -} Saudi Arabia, Jordan, Morocco

\section{Summary}

The article aims to explain the constitutional and political role of the royal family in three Arab monarchies: Saudi Arabia, Jordan and Morocco. The introduction discusses the typology of monarchy, including the division into individual monarchies with the marginal role of the royal family and monarchies where the royal family holds a significant position. Through the use of a comparative method, the article analyses the constitutional position of the royal family according to the normative acts of the studied states. The next part of the article attempts to answer the following questions: what place does the royal family occupy in the 
political system of their country? do its members have individual competences or share them with other state authorities? The importance of factors such as religion and family history will be emphasized. In addition, the author will indicate areas of social and political life that may be influenced by members of the royal family.

Keywords: monarchy, royal family, Middle East, constitution, politics

\section{Значение коромевской семьи в помитике и госуАарственном управмении арабских монархий - СауАовской Аравии, ИорАании и Марокко}

\section{Резюме}

Целью статьи является определение роли и значения позиции королевской семьи в государственном устройстве трех арабских монархий: Саудовской Аравии, ИорАании и Марокко. Во вступлении будет оговорена типология монархии, в том числе Аеление монархии на индивиАуальную с маргинальным значением королевской семьи, а также семейную монархию со значительной ролью королевской семьи. С помощью сравнительного метода будет проанализирована управленческая позиция королевской семьи в нормативных актах отАельных стран. В слеАующей части статьи будет преАпринята попытка ответа на вопрос, какое место в политической системе занимает королевская семья, компетентны ки ее члены или сотруАничают с Аругими государственными органами. Будет выделено значение таких факторов, как религия и история рода. Кроме того, будут обозначены обмасти общественно-политической жизни, на которые могут влиять члены королевской семьи.

КАючевые слова: монархия, королевская семья, Ближний Восток, конституция, политика

mgr Anna Oliwa

Uniwersytet Pedagogiczny im. KEN w Krakowie ul. Podchorążych 2

30-084 Kraków

e-mail:anna.oliwa@outlook.com 